\title{
Evaluation of beach rehabilitation success, Turners Beach, Tasmania
}

\author{
Elizabeth Johnston • Joanna C. Ellison
}

Received: 26 September 2013 /Revised: 7 July 2014 / Accepted: 8 July 2014 /Published online: 25 July 2014

(C) The Author(s) 2014. This article is published with open access at Springerlink.com

\begin{abstract}
Beaches worldwide have been subjected to human impacts by the trampling of vegetation, leading to exposure that increases their vulnerability to erosion. Rehabilitation efforts have included dune revegetation and control of human, access along with information signs for public education. Long term evaluation of the success of these is largely lacking, particularly in Australia where there has been significant Natural Resource Management funding in the last 20 years. This study used beach monitoring profiles, sediment analysis, historical photographs and community surveys to evaluate beach rehabilitation activities at Turners Beach, Northern Tasmania, where significant community effort has been invested. Results showed that the western and central sections of Turners Beach have experienced overall accretion since 2006, with development of a foredune and evidence of marine derived sediment deposition. The eastern section continued to show some erosion, with informal access tracks remaining despite fencing and signage. After 15 years of rehabilitation, historical photographs and community survey showed that human access control using boardwalks and vegetation replanting has been successful, justifying the community effort and federal government funding that was invested at the time, and ongoing community and local government maintenance since. Dune fencing was also found to have partly contributed to rehabilitation success, while placement of rocks along the shoreline appeared to have had mixed results, and information signs were found to be the least successful management practice. Topographic survey of beach profiles was confirmed by this study to be an effective method for evaluation of erosion, justifying the involvement of surveyors, with such long term monitoring being beyond the scope of most
\end{abstract}

E. Johnston · J. C. Ellison $(\bowtie)$

School of Land and Food, University of Tasmania, Locked Bag

1370, Launceston 7250, Tasmania, Australia

e-mail: Joanna.Ellison@utas.edu.au projects. Community survey was also confirmed to be a valuable tool in identifying long term changes, and community participation to be successful in increasing the integrity and resilience of beach and dunes areas.

Keywords Erosion $\cdot$ Beach profile $\cdot$ Rehabilitation $\cdot$ Access control $\cdot$ Replanting $\cdot$ Community survey

\section{Introduction}

Beaches provide a range of ecosystem services (Defeo et al. 2009) as well as important recreational and amenity values, which attract high intensity use and adjacent development. Human stressors impact upon beach habitats such as successional fore dunes, disturbing vertebrates and shorebirds that nest in the backshore (Santoro et al. 2012), and leading to erosion (Bird 2008; Defeo et al. 2009; Santoro et al. 2012). While beaches undergo cyclic changes of erosion and deposition over longer time scales (Bird 2008), up to $70 \%$ of the world's beaches are experiencing erosion (Bird 1985; Church et al. 2008), and this is expected to further increase with global sea level rise (Nicholls et al. 2007; Bird 2008).

In southern Europe, beaches came under severe pressure following tourist urbanisation from the 1960's (Gómez-Pina et al. 2002), leading to dune rehabilitation efforts. Extensive beach and dune degradation in Spain was successfully restored in the 1990's using fencing to reduce effects of human trampling, elevated dune walkovers to provide access from the road to the beach, and information posters to educate the public regarding damage (Gómez-Pina et al. 2002).

In western France, erosion of coastal dunes occurred following heavy tourist trampling, and in the late 1980's was restored using access control fencing and vegetation replanting (Rozé and Lemauviel 2004). Ten years later the restoration procedures were shown to be successful, with 
vegetation cover restored onto bare soil, and accumulation and progradation of the dunes. These projects used European marram grass (Ammophilia arenaria), a vigorous pioneer beach grass that has been introduced for beach stabilisation in North America, South Africa and Australia, though later viewed to be an invasive weed that out-competes native biodiversity (Hertling and Lubke 1999; Webb et al. 2001; Hayes and Kirkpatrick 2012).

In Australia, following community concern about erosion and degradation of the coastline, rehabilitation has been undertaken by local councils, natural resource management (NRM) agencies, and community voluntary groups. Landcare commenced in the mid-1980's, carrying out rehabilitation projects such as fencing native vegetation from stock access, weed control, and replanting with native species to reduce riparian and coastal erosion.

Since 1990, the Australian federal government has funded seven NRM programs, these tending to increase in both budget and timespan (Hajkowitz 2009). Community capacity building, attitude and awareness change and property management planning were the foci of the first National Landcare Program in 1990-1991 (Hajkowitz 2009) and in 1997 community environmental management was boosted by the establishment of the Natural Heritage Trust (Lefroy et al. 2012), funded by the sale of one third of the public telecommunications company Telstra (Robins and Kanowski 2011). Over this period over $\$ 4.2$ billion of public funds were invested in environmental management, most of it through Landcare and other volunteer community groups (Hajkowicz 2009) including Coastcare. By 1990 there were 300 community associations engaged in practical Coastcare projects (Youl et al. 2006).

Since the emergence of NRM programs in Australia, administering agencies have been challenged by problems of evaluating expenditure (Hajkowitz 2009). While the effectiveness of this investment was regularly audited, the first in 1997 commented "it is difficult to determine the extent to which programs are achieving their intended outcomes", and each successive audit echoed that concern (Lefroy et al. 2012). Many of the projects were believed to be too small and fragmented to make any measurable impact on the processes governing the landscape at larger scales, and long term evaluation was unrealistic (Lefroy et al. 2012).

While long term outcomes of projects concerning water quality in agricultural catchments and vegetation in rural landscapes were later assessed (Ross et al. 2012), there has been no evaluation of the long term effectiveness of coastal rehabilitation projects. Despite the outlay of large amounts of government money and community in-kind effort on these projects, the evaluation of the long term success of these initiatives in managing coastal erosion remains a poorly studied area.
Objective

This study evaluated the long term success of a variety of community coastal rehabilitation works at Turners Beach, North Tasmania. Beach monitoring profiles, sediment analysis, historical photographs and community surveys are used to investigate the effectiveness of rehabilitation in reducing erosion.

\section{Study site}

Tasmania extends across a latitudinal range of $39^{\circ} 40^{\prime}-43^{\circ} 20^{\prime}$ $\mathrm{S}$ and is the southernmost State in Australia. As the only island State, Tasmania has longer coastlines per unit land area that all others, with c. 2,200 km (Zann 1995), and beach length totalling $878 \mathrm{~km}$ on the main island alone (Short 2006). Turners Beach is located on the central north coast of Tasmania (41 ${ }^{\circ} 10^{\prime}$ 'S $146^{\circ} 14^{\prime} \mathrm{E}$; Fig. 1), with semi-diurnal tides with a mean spring tidal range of $2.5 \mathrm{~m}$ (Short 2006).

The Forth Estuary to the east has a total catchment area of $1,125 \mathrm{~km}^{2}$ (Edgar et al. 1999), with a series of dams and diversions for hydroelectric activities (Hydro Tasmania 2013). The central north coast of Tasmania experiences a maritime climate, with maximum summer and winter temperatures averaging $21{ }^{\circ} \mathrm{C}$ and $13{ }^{\circ} \mathrm{C}$ respectively. The mean annual precipitation is $778 \mathrm{~mm} \mathrm{a}^{-1}$, with a winter maximum (Bureau of Meteorology 2013).

The coast faces Bass Strait located between Tasmania and Victoria, with a mean depth of 50-70 m, and steeply deepening to over $4 \mathrm{~km}$ in depth on each side. Lateral flushing of Bass Strait results from inflow of three primary water masses, the South Australian Current from the west, the East Australian Current from the north east which has greater influence in summer, and the sub-Antarctic surface water from the south (Sandery and Kampf 2007). The north coast of Tasmania is largely sheltered from easterly and westerly swells by the Bass Strait islands (Davies and Hudson 1987),

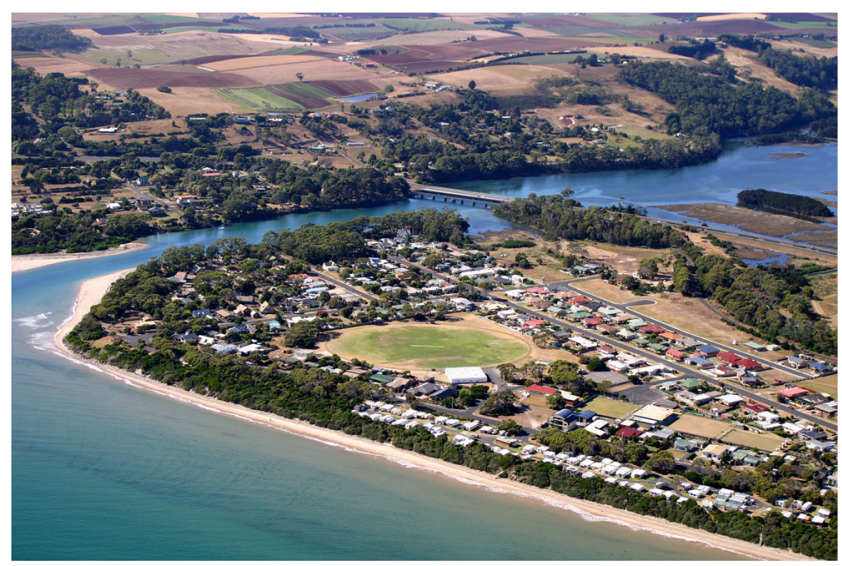

Fig. 1 Oblique aerial photograph of Turners Beach in 2006 (Photo: Daryl Jones) 
resulting in a lower energy environment when compared with the west and east coasts of Tasmania. While the north-westerly wave approach along the central north coast of Tasmania would be expected to produce longshore currents, beaches rather experience negligible longshore sediment transport, with sediment circulated within small, defined coastal compartments (Davies 1973).

Relative sea level in Tasmania has been within half a metre of present sea level for much of the last 6000 years (Gehrels et al. 2012). Analysis from a tidal mark struck in Southern Tasmania in 1841 shows that mean sea level has risen by around $14 \mathrm{~cm}$ between 1841 and 2002, at an overall rate of $0.8 \pm 0.2 \mathrm{~mm} \mathrm{a}^{-1}$ (Hunter et al. 2003). With data only since 1993, the Burnie tide gauge station (around $30 \mathrm{~km}$ north-west of Turners Beach) has too short a record to show a reliable trend (Pugh 1987).

The township of Turners Beach (population 1,595) is located at the western mouth of the Forth River, on low undulating topography behind the frontal dunes. While European settlers arrived in 1840, township growth has only occurred since the 1950s (Central Coast Council 2011). Turners Beach is $2.2 \mathrm{~km}$ in length, consists of a narrow, moderately steep high tide beach comprised of sand and shingle, leading to a low gradient low tide terrace of sand, which extends to $150 \mathrm{~m}$ at spring low tide (Short 2006). Northern Tasmanian beach sand was predominantly derived from the continental shelf during and after the postglacial marine transgression (Thom and Roy 1985; Davies and Hudson 1987). Since the transgression, the majority of sediment input is derived from marine sources or reworked coastal sediment. Rivers, such as the Forth River, supply negligible sediment to the northern coastline at the present time (Davies and Hudson 1987).

Erosion of the Turners Beach foreshore, in particular the eastern section, has been occurring for over 20 years. Several coastal protection and rehabilitation works have been undertaken since the mid-1990s, summarised in Table 1. A key goal has been to better manage human and vehicle access to the beach, in order to allow vegetation recovery, and increase stability and integrity of the dunes.

\section{Methods}

Evaluation of long-term beach monitoring profiles and historical photographs were used to indicate the success of community rehabilitation efforts to reduce erosion. Beach sediment was analysed to give insight into its sources, movement and properties. Community members were interviewed to survey their opinions regarding the success of beach rehabilitation activities.

Historical photographs and previous beach topographic profiles were available for Turners Beach, and these were re- surveyed. Five beach profiles with previous data were available, three along the main seaward beach and two within the Forth River mouth (Fig. 2). Three sites on the main beach were previously measured by the Tasmanian Shoreline Monitoring and Archiving project (TASMARC) (Antarctic Climate and Ecosystems Cooperative Research Centre 2013) in 2006, 2007 and 2010, along with an additional measurement in 2011 for the western TASMARC site. Two transects positioned near the mouth of the Forth estuary were measured 10 years previously by the second author. Each transect was re-surveyed using a Topcon GTS-303 Total Station, the profile extending from the top of the foredune to the low water section of the beach.

Surface sediment was sampled across each transect, and analysed for properties of texture, roundness and mineral composition. Particle grain size distribution was determined using sieve analysis (McManus 1988), and carbonate content was examined by the addition of $10 \% \mathrm{HCl}$, and microscopically assessing the degree of dissolution. Particle roundness was assessed microscopically by comparison with the Wadell roundness chart (Pettijohn 1975).

Qualitative surveys were used to investigate local knowledge of coastal morphological changes and management activities at Turners Beach, interviewing members of the Turners Beach Coastcare Group and other residents. Semi-structured interviews and questionnaires were used, which allowed for the maintenance of focus but enabled participants to describe their own observations or perceptions (Dunn 2000). Interviews with residents have previously been used to gain insights into coastal erosion and management (Mimura and Nunn 1998; Hertling and Lubke 1999; Semken et al. 2011; Apine 2011).

\section{Results}

\section{Beach profiles}

Five beach profiles were surveyed during this study (Fig. 2), three at $500 \mathrm{~m}$ intervals on the seaward beach with data back to 2006 , and two inside the estuary mouth with data back to 2002. Results are described below from west to east.

The beach at Transect 1 (Fig. 3) consisted of upper intertidal shingle and lower more level intertidal sand, separated by swash-backwash sorting. Public access through the dunes is by a single boardwalk, with dense native revegetation either side. The foredune was covered with dense vegetation, and no erosion scarp was evident. Previous transect surveys indicated erosion of the foredune 2006-2007 losing about $7 \mathrm{~m}^{2}$ of sand from the profile, followed by re-deposition 2010-2011, returning the foredune to the 2006 position, and the primary dune showed accretion 2006-2012. 
Table 1 Beach rehabilitation actions undertaken at Turners Beach, Tasmania, 1998-2012

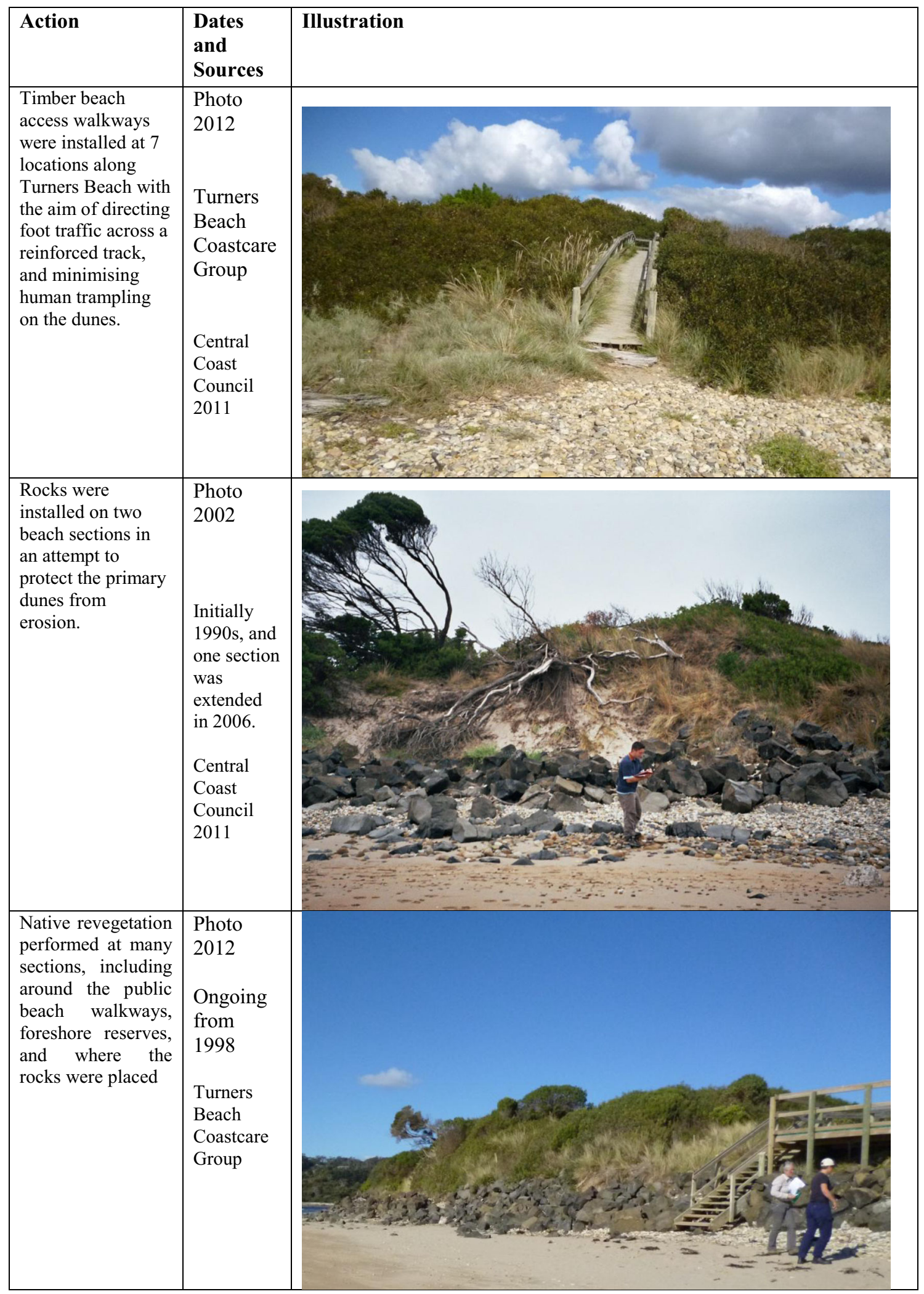

The beach at Transect 2 (Fig. 4) was similar to Transect 1, with upper intertidal shingle and lower intertidal more level sand. Public access to the beach at this site was restricted to a single boardwalk, and the foredune was densely vegetated 
Table 1 (Continued)

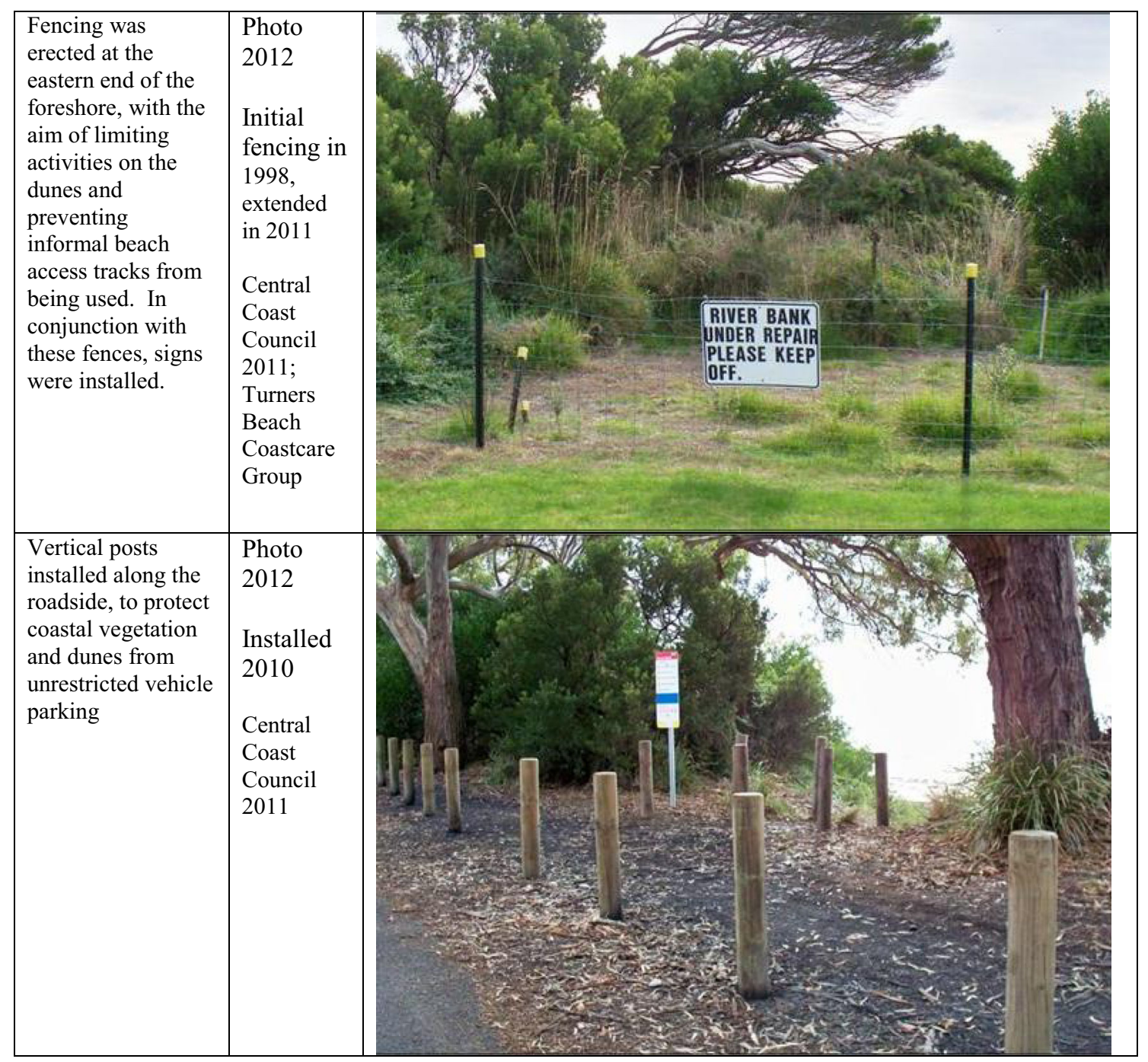

with no erosion scarp present. Surveys showed a foredune developed from 2007-2012, accreting over $8 \mathrm{~m}^{2}$ of sand across the profile, and the foredune behind this also showed accretion (Fig. 4). The 2007 survey indicated a minor decrease in the gradient of the lower sandy beach compared to the 2006 survey.

The beach at Transect 3 (Fig. 5) was similar to Transects 1 and 2, with upper intertidal shingle and lower intertidal more level sand. While there was no formal beach access track in the vicinity of this site, an informal track showing signs of current use extended from the road above to the dune top, in close proximity to the survey transect. In contrast to the previous transects, there was a prominent erosion scarp at this site, with exposed roots and fallen clumps of vegetation on the face of the scarp and at the base. Comparison with earlier transect surveys showed a retreat of the foredune of $3 \mathrm{~m}$ between 2006 and 2012, however the top of the scarp experienced accretion of around $65 \mathrm{~cm}$ during the same period.
The intertidal beach between 0 and $1 \mathrm{~m}$ above MSL showed slight erosion 2006-2010, however this was balanced by accretion 2010-2012 (Fig. 5).

Transects 4 and 5 inside the Forth estuary mouth had the same starting point but different orientations (Fig. 2). The beach at this site was predominantly sand, with a combination of shingle and sand towards the seaward end of each transect. In addition, shingle was present on the backshore of Transect 4. Vertical poles to prevent vehicle access to the upper primary dune were present along the side of the road above this site (Table 1), beach access was across a wooden staircase constructed in 1998, at which time dunes were revegetated with native species by a Coastcare project. Survey results (Figs. 6 and 7) showed stability of the foredune 2002-2012 across the first $3 \mathrm{~m}$ of each profile, but a loss of sand and shingle from the upper beach 2002-2012 of about 1.5-1.8 m, and even more loss at lower intertidal levels. The beach profiles however remained convex. 
Fig. 2 Map of Turners Beach, showing locations of transect profiles and sites mentioned in the text (Adapted from DPIWE 2012)

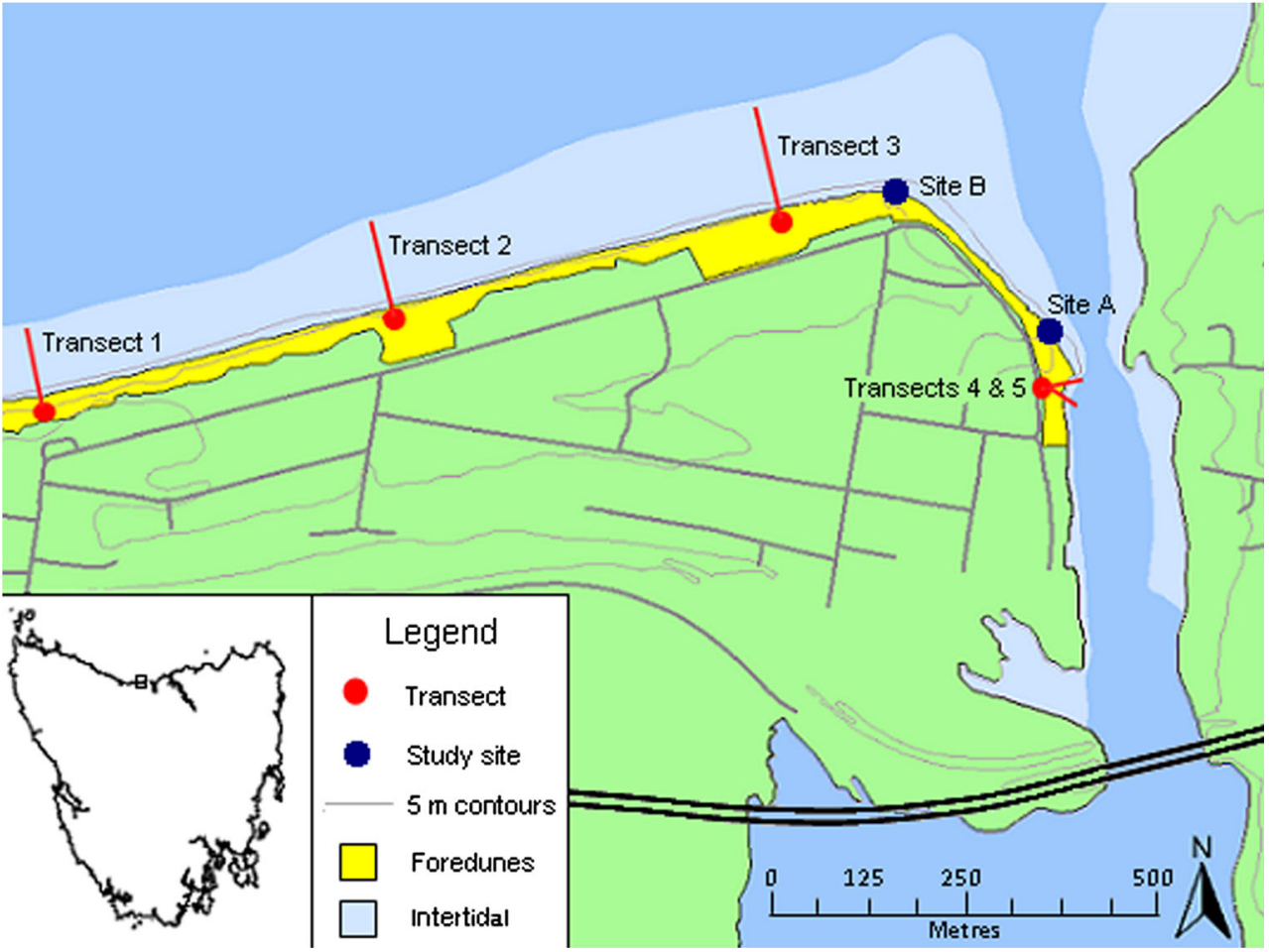

Sediment analysis results from transects are shown in Table 2, recording similar results from Transects 3, 4 and 5 of sub-rounded, fine to medium sized sand. The western section of Turners Beach at Transect 1 was coarser, with medium grained sand, which was sub-angular on the foredunes and sub-rounded at the seaward margin of the profile. All transects showed moderately sorted to moderately well-sorted sediment. Analysis of mineral composition of the sand samples showed that the eastern beach at Transects 3, 4 and 5 are predominantly quartz dominant though with a high percentage of carbonate relative to other minor minerals present (Table 2). By contrast, all sand samples obtained from Transect 1 were carbonate dominant, and the sediment at
Transect 2 was quartz dominant sediment on the upper dune profile, and carbonate dominant sediment on the seaward margin of the profile.

\section{Historical photographs}

Site A is located adjacent to Transects 4 and 5 (Fig. 2), close to the mouth of the Forth estuary and dune erosion was evident in the 1990s largely as a result of human access and trampling. In 1998 the Coastcare group project installed a public staircase leading from the road behind to the beach, erected a fence to limit public access outside of the staircase, and placed rocks along the shoreline to prevent undercutting of the dune. The
Fig. 3 Beach profile surveys at Transect 1, Turners Beach (VE $\times$ 7)

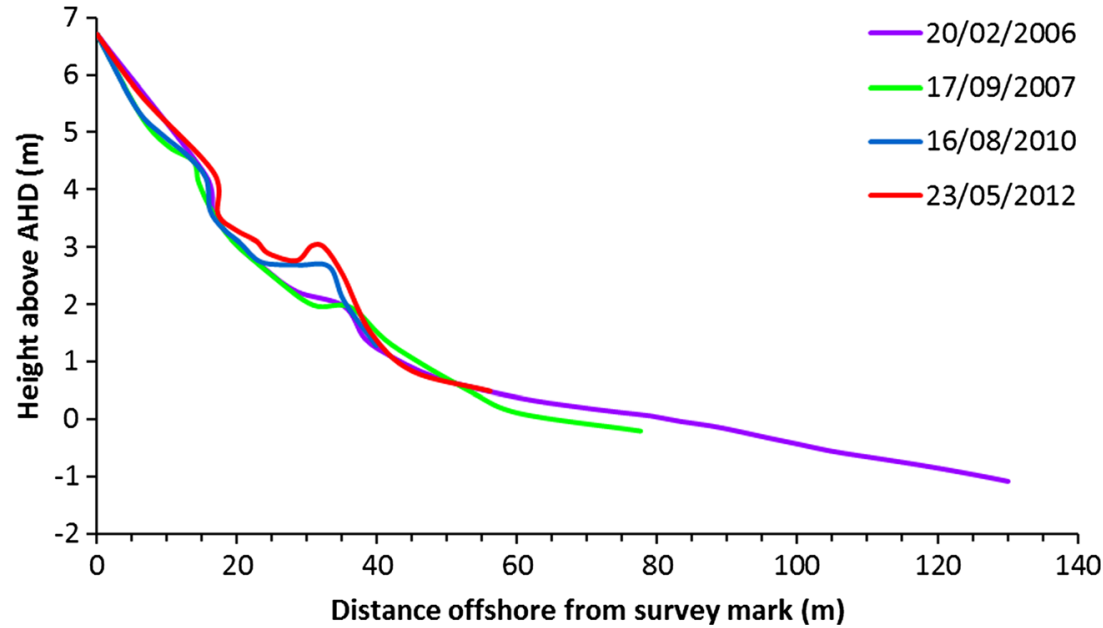


Fig. 4 Beach profile surveys at Transect 2, Turners Beach (VE $\times$ 8)

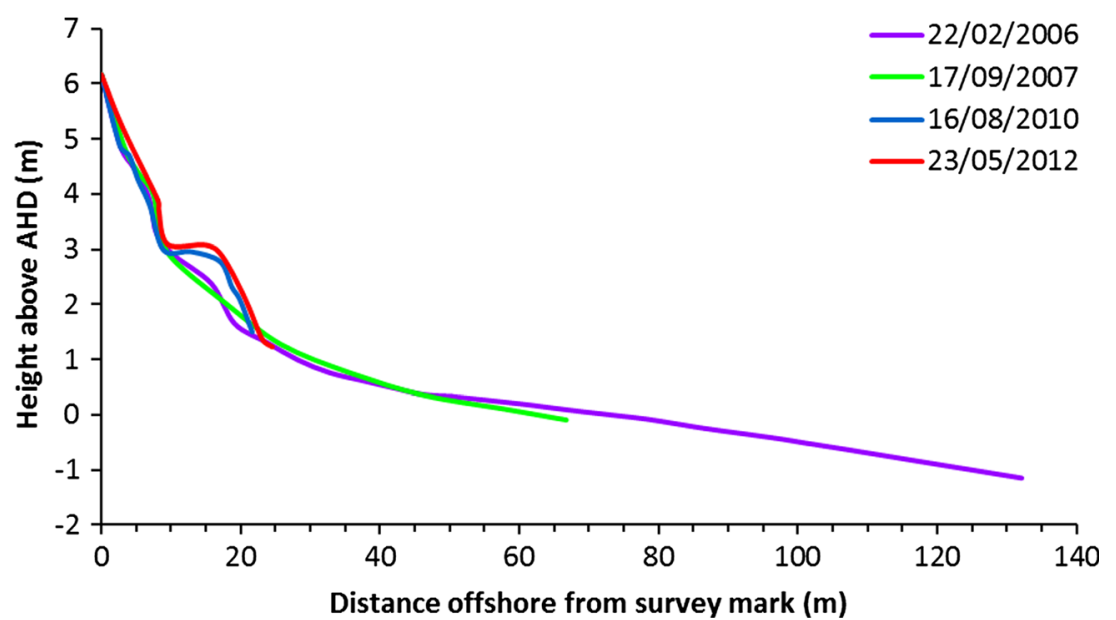

primary dune was subsequently revegetated using native plants by the Turners Beach Coastcare volunteers.

Comparison of the 2002 historical photograph with 2012 observations of this section (Fig. 8) showed accretion of sand and organic matter over the rock area, such that in 2012 the rocks were barely visible (Fig. 8b). In addition, the dune is now largely covered with coastal grass and shrubs (Fig. 8b), and accretion of the backshore has occurred with the bottom two steps of the public staircase at the backshore becoming covered by shingle/sand deposits (Fig. 8b).

Site B is located on the eastern end of Turners Beach (Fig. 2) and has been eroding over the last several decades, particularly as a result of a storm in 1995. In 1998 large rocks were placed on a section to the east (Table 1), and more rocks were placed towards to the west in 2006 (Fig. 9), along with a public walkway and staircase constructed for public access to the beach from the road behind (Table 1). The dunes were also revegetated by the Turners Beach Coastcare volunteers, and the top of the dunes fenced with signage to prevent access (Table 1).

Comparison of 2002 historical photographs with 2012 observations of this section showed integration of shingle with the installed rocks, and dense vegetation developed on the upper dune (Fig. 9b). In addition, the dune scarp erosion evident in 2002 (Table 1) had recovered by 2012. However, in 2012 some of the dune top fences were in a state of disrepair, and informal beach access tracks were still in use.

Qualitative surveys

Respondents to the survey and interview were all permanent residents of the Turners Beach community for a length of time ranging from 2-42 years, and of the total of 18, 8 were members of the Turners Beach Coastcare Group.

Regarding past coastal changes, $89 \%$ of the participants perceived the coastal erosion at Turners Beach to be a gradual phenomenon, significantly accelerated during a storm or flood event when in combination with a high tide. In addition, $56 \%$ of the respondents held the view that the erosion had become more severe in recent years, and the coast appeared to have become more susceptible to damage from storm and flood events. A total of $35 \%$ of the respondents identified a shift over time of the main area that was experiencing erosion, from Site A, to Site B (Fig. 2). A reduction of the sandy beach at the
Fig. 5 Beach profile surveys at Transect 3, Turners Beach (VE $\times$ 8)

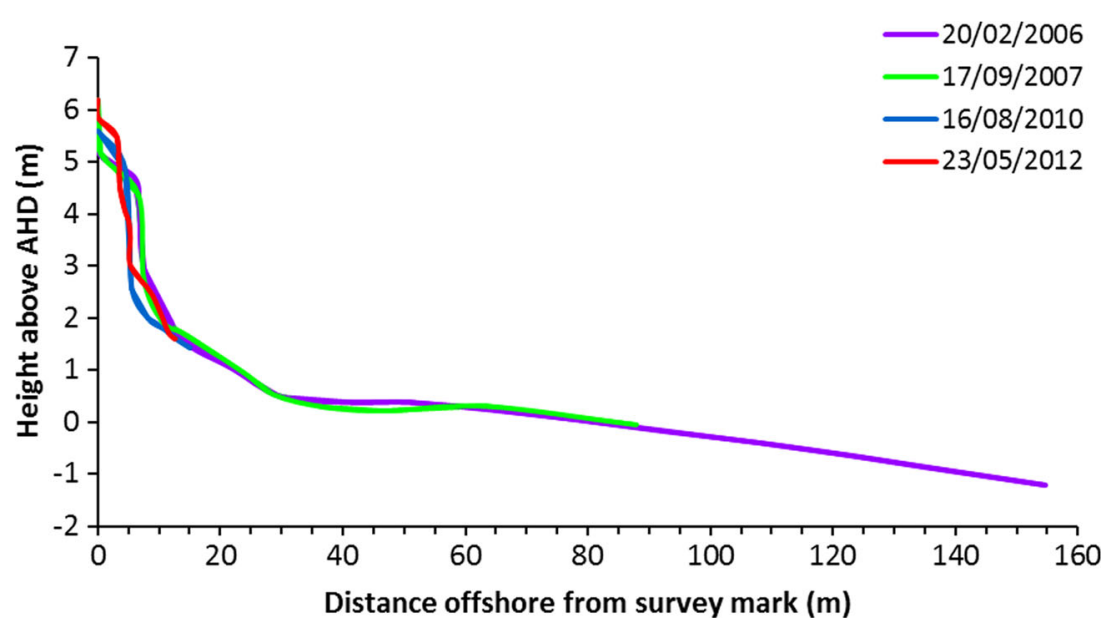


Fig. 6 Beach profile surveys at Transect 4, Turners Beach (VE $\times$ 3)

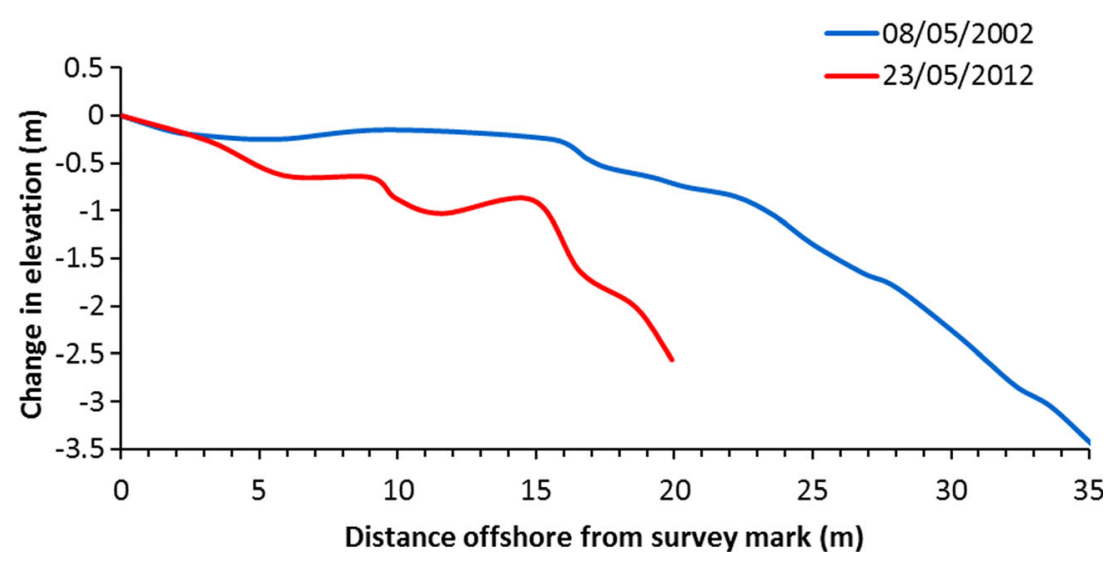

mouth of the river and an increase in shingle deposits was observed by a small number of respondents.

Results of community opinion on factors that may be causing coastal erosion at Turners Beach are shown in Fig. 10. Storm events were believed to be one of the primary causes of coastal erosion by $100 \%$ of the respondents, and $89 \%$ of respondents considered that wave action at high tide, and flooding of the Forth River were also major causative factors. A total of $56 \%$ of the respondents believed that human foot traffic over the dunes, together with the activities of children in the dunes, were contributing factors to coastal erosion. Sea level rise was the least popular cause of erosion.

Participants commented on the success of beach rehabilitation actions (Table 1), with results shown in Fig. 11. Of the six management practices utilised, the introduction of public beach walkways to reduce pedestrian access over dunes was considered to be the most effective, with $94 \%$ of respondents relating that this management practice was successful. The placement of posts along the roadside to prevent vehicle access or parking on the shoreline (Table 1) was regarded by
$89 \%$ of the respondents to have reduced erosion. Overall, shoreline revegetation was regarded as being relatively successful, with $56 \%$ of the participants believing this measure reduced erosion, and the remainder indicating that revegetation may have been successful.

The success of dune fencing to prevent human access received varied responses, being considered successful by $50 \%$ of the participants but remaining respondents indicated that a number of the dune fences were in need of maintenance or improvement, and were aware of people disregarding the fences. Placement of rocks along the shoreline in an attempt to reduce erosion also incurred mixed views, with $50 \%$ of respondents indicating that they believed the erosion was reduced at the locations at which the rocks were placed, but around half of these respondents also raising concerns about the effects that the rocks may be having on adjacent sections of the shoreline through alteration of wave action. Informative signage was regarded to be the least effective management practice, with only $17 \%$ of the participants considering the signs to be sufficiently informative about coastal rehabilitation, and the importance of minimising disturbance to the dunes.
Fig. 7 Beach profile surveys at Transect 5, Turners Beach (VE $\times$ 3)

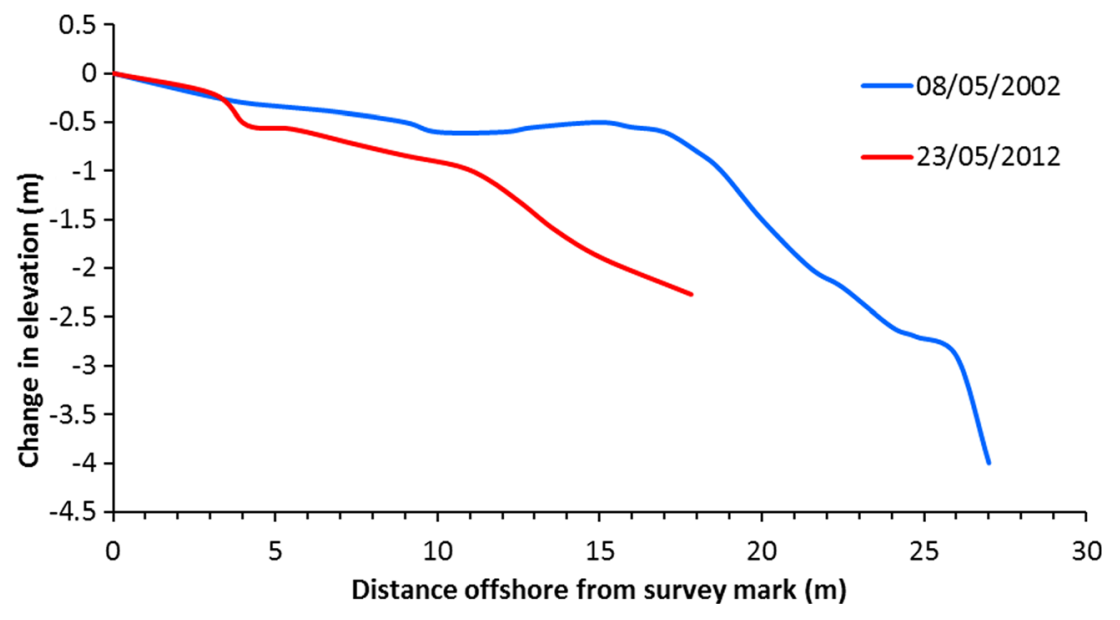


Table 2 Mean surface sediment characteristics from the beach and dune sections of transects $1-5$, Turners Beach

\begin{tabular}{lllllll}
\hline Transect & Location & Mean grain size $(\mathrm{mm})$ & Mineralogy & Roundness & Sorting & Skewness \\
\hline 1 & Dune & 0.31 & Carbonate $(70 \%)$ dominant & Subangular & 0.70 & -0.08 \\
& Beach & 0.23 & Carbonate $(80 \%)$ dominant & Subrounded & 0.71 & 0.52 \\
2 & Dune & 0.21 & Quartz dominant, 20\% carbonate & Subangular & 0.67 & -0.14 \\
& Beach & 0.18 & Carbonate $(70 \%)$ dominant & Subrounded & 0.64 & -0.20 \\
3 & Dune & 0.17 & Quartz dominant, 20\% carbonate & Subrounded & 0.53 & -0.21 \\
& Beach & 0.19 & Quartz dominant, 30\% carbonate & Subrounded & 0.70 & -0.31 \\
45 & Dune & 0.22 & Mixed quartz and carbonate & Subrounded & 0.77 & -0.34 \\
& Beach & 0.18 & Quartz dominant, 30\% carbonate & Subrounded & 0.60 & -0.08 \\
\hline
\end{tabular}

\section{Discussion}

Beach profiles on the seaward facing beach (Figs. 3, 4 and 5) showed a narrow beach and swash zone, lacking bars and cusps but featuring gravel deposits both on the beach and in dunes behind. Beach profile re-measurement over time demonstrated different trends, with Transects 1 and 2 both showing accretion of a foredune between 2.0 and $3.5 \mathrm{~m}$ above MSL over the period 2006-2012 (Figs. 3 and 4), changing the overall profile from concave to convex. Prograding beaches are generally convex, often accompanied by developing berms or beach terraces, and the building of foredunes above the high tide level (Bird 2008). Since 2006, the elevation of upper beach shingle has increased by $0.7-1.0 \mathrm{~m}$ at Transects 1 and 2 (Figs. 3 and 4). For a $10 \mathrm{~m}$ stretch of beach, this would result in an increase in sediment volume of approximately 55$80 \mathrm{~m}^{3}$.

By contrast, the eastern section of Turners Beach and the shoreline within the Forth River mouth were shown to have eroded (Figs. 5, 6 and 7), with Transect 3 showing an increasingly concave profile over time (Fig. 5), with continuing dune front retreat with an active dune scarp of around $2.5 \mathrm{~m}$ high with a gradient of greater than $30^{\circ}$, where the strength of unconsolidated sediments is reduced (Nichols 2009). For a $10 \mathrm{~m}$ stretch of coastline, this erosion would result in a loss of sediment of approximately $75 \mathrm{~m}^{3}$ in volume.

Beach profiles within the mouth of the Forth River (Figs. 6 and 7) showed steep convex profiles with stability in the frontal dunes. Loss of sediment from the profile that occurred 2002-2012 was from truncation of the lower intertidal beach, and a likely explanation is channel movement in the lower estuary associated with river floods.

Erosion at the eastern section of Turners Beach may be attributed to a number of factors. While recent measures have been taken to control human access, the eastern section of Turners Beach is still showing impacts, with informal access tracks and dune disturbance. While respondents to the qualitative survey reported a correlation between significantly enhanced erosion events and storm or flood events, reduction of vegetation cover and disaggregation of sand reduces the resilience of dunes to erosive events (Defeo et al. 2009).

Sediment results showed a relatively low roundness value of sediment (Table 2), which is typical of the low wind and wave energy conditions of the northern coast of Tasmania (Davies 1978). Beach sediments exhibit greater sorting in high wave energy (Bird 2008), and the moderately sorted to moderately well sorted sediment at Turners Beach reflects the relatively low wave energy of North Tasmania.

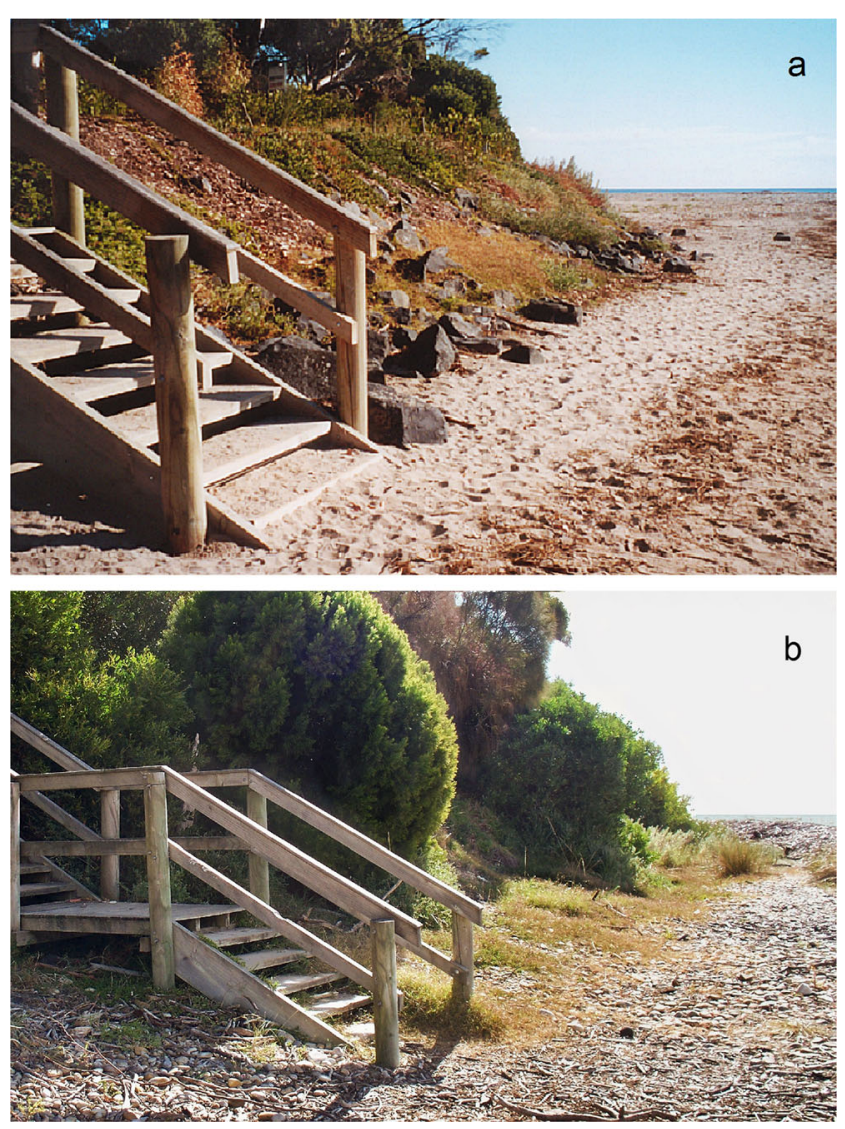

Fig. 8 Public staircase and dune revegetation at Site A. a: 2002 (Photo: J. Ellison), b: 2012 (Photo: E. Johnston) 

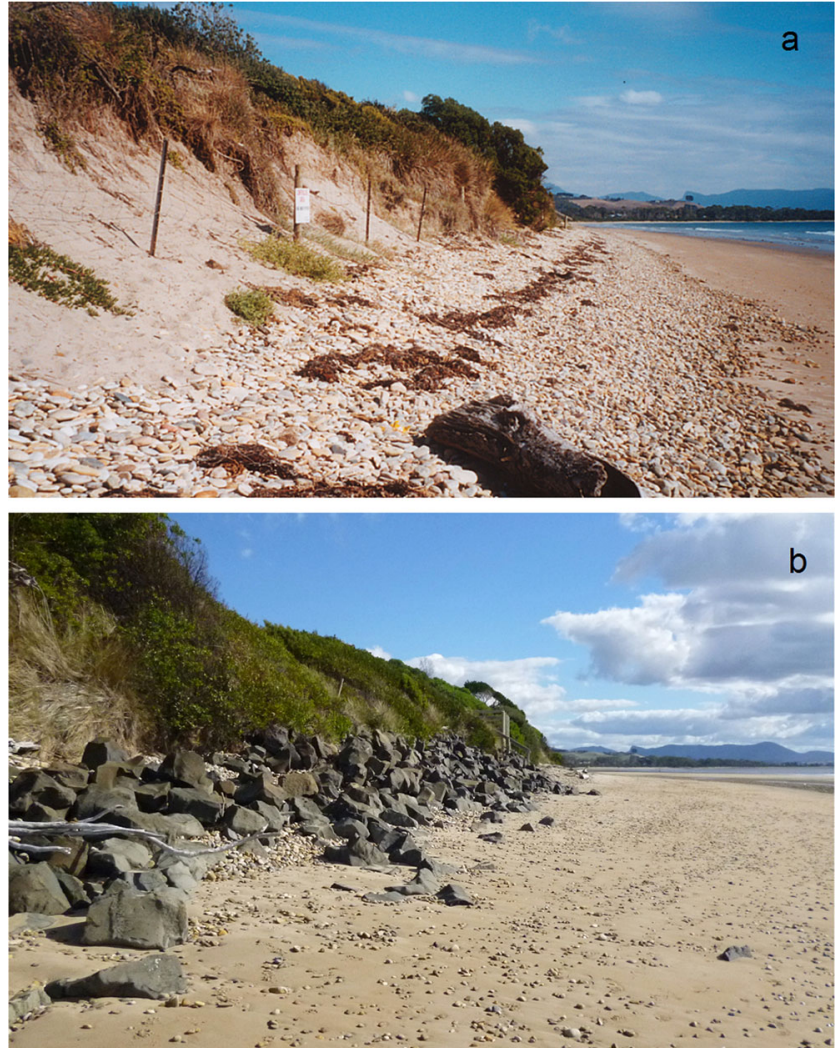

Fig. 9 Erosion at Site B at the eastern end of Turners Beach. a: 2002 (Photo: J. Ellison), b: 2012 (Photo: E. Johnston)

The presence of a significant proportion of carbonate indicates that sediment derives from marine origins (Davies and Hudson 1987). Transect 1 was carbonate dominant (Table 2), suggesting that the foredune sediment originated from beach sand, adding to evidence of shoreline progradation at this site (Fig. 3). Sediment at Transect 2 ranged from quartz dominant sediment on the upper profile, to carbonate dominant sediment on the seaward portion of the profile (Table 2), indicating that the lower beach is receiving marine sand supply. Higher levels of carbonate may also be attributed to low sediment inputs from the hinterland and weak longshore drift (Davies and Hudson 1987). The eastern section of Turners Beach consisted of finer, more rounded and more quartz dominant sediment than the western section (Table 2). This suggests that sediment eroding from along the foredunes from Transect 3 to Site A (Fig. 2) is being deposited further within the Forth River mouth.

The success of public access walkways in stabilising and reversing shoreline erosion can be observed at Transects 1 and Transect 2, where human access to the beach at these locations is limited to the walkways. Beach profiles and field observations indicated that the foredune is densely vegetated, no erosion scarp is evident, and accretion of shingle has occurred at this site (Figs. 3 and 4), showing that management activities have been successful in reversing erosion. The introduction of public walkways was viewed as the most successful in reducing erosion (Fig. 10), closely followed by vehicle exclusion poles. At the more highly impacted eastern end of the beach where both have been introduced, over 10 years the dune has stabilised assisted by revegetation (Fig. 8). Ten years after revegetation of bare dunes in Brittany, Rozé and Lemauviel (2004) also found established vegetation cover, progressing in succession but this not as yet accomplished. Complete restoration of such degraded habitats can take considerably longer than 10 years (Santoro et al. 2012; Landi et al. 2012).

Revegetation of dunes with native grasses and shrubs has been successful, as indicated by most participants in the qualitative survey, and the remainder indicating that revegetation was possibly successful (Fig. 10). The foredunes of most of the beach are now well vegetated (Table 1, Figs. 8 and 9), further confining public access to walkways. Where public access has not been confined to walkways, erosion continues to be a problem (Fig. 5), were dune fencing was
Fig. 10 Summation of interview respondent views on causes of coastal erosion

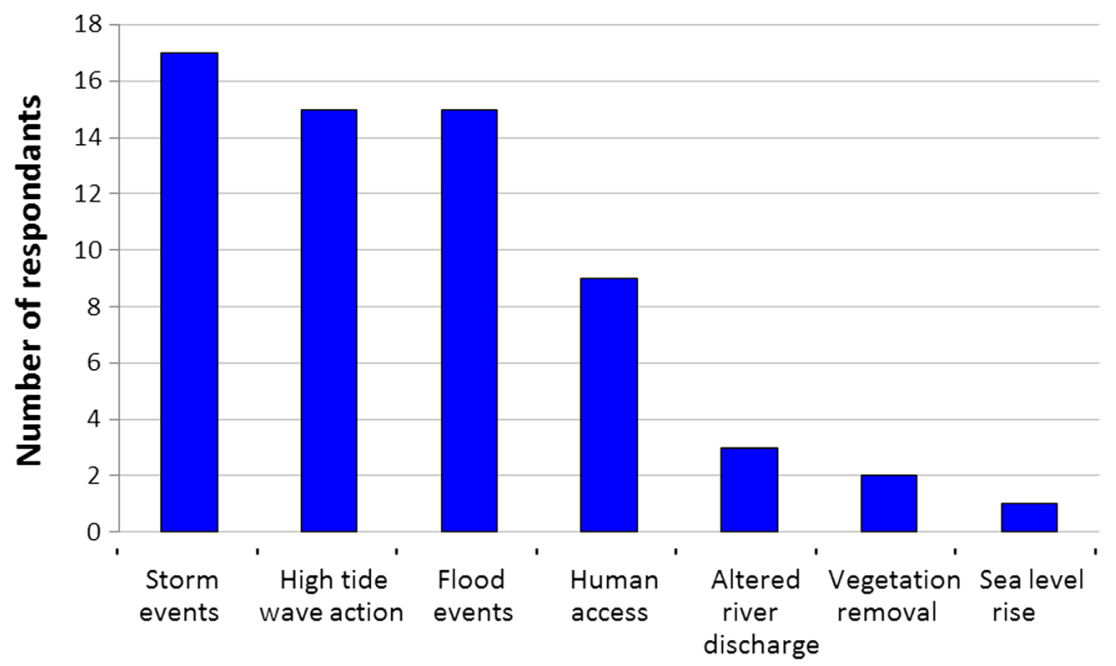

Cause of shoreline erosion 
Fig. 11 Summation of interview respondent views on coastal management outcomes, Turners Beach. a. Public beach walkways in the reduction of pedestrian access over dunes. b. Dune fencing in the prevention of pedestrian access. c. Placement of rocks along sections of the shoreline in the reduction of erosion. d. Placement of posts along the roadside in the prevention of vehicle access/ parking on the shoreline.

e. Revegetation of the dunes with native grasses and shrubs.f Signs informing the public about coastal rehabilitation and the importance of minimising disturbance to the dunes a) Public walkways

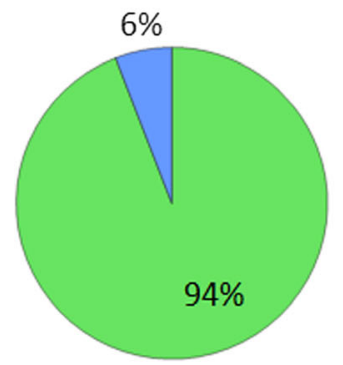

d) Vehicle prevention poles

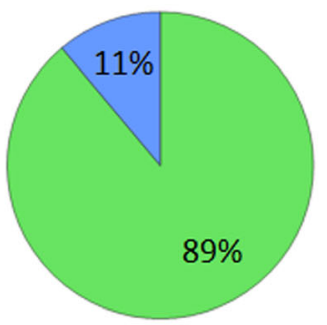

Successful b) Dune fencing

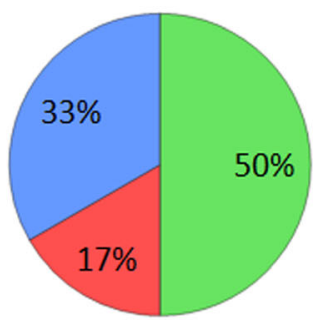

e) Shoreline revegetation

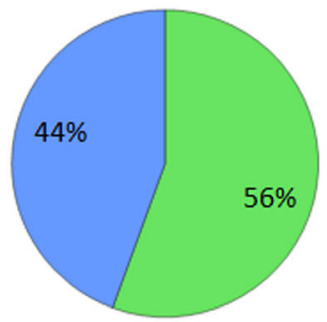

Possibly successful c) Rock placement

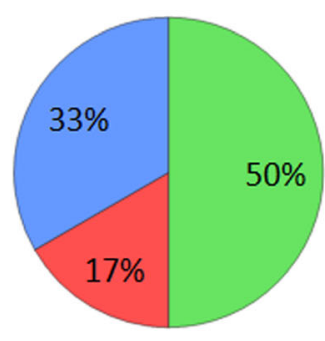

f) Signs

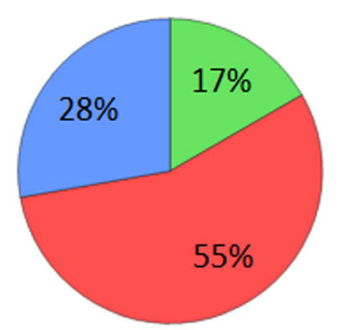

Not successful installed (Table 1) to help reduce pedestrian access over the dunes, a similar intention to walkways. However, while dune fencing was perceived as being successful by $50 \%$ of respondents to the survey it was viewed as unsuccessful by $17 \%$ (Fig. 10). Fencing has contributed to success at Site 2 (Fig. 9), with growth of dense foredune vegetation and disused informal access tracks. However, some of these fences are in a state of disrepair, allowing for a small number of informal beach access tracks to remain in used, causing erosion of the upper beach of around $3 \mathrm{~m}$ since 2006 (Fig. 5).

The placement of rocks along the shoreline to increase lower dune resilience to erosion appears to have had mixed success. At the eastern end of the beach (Fig. 9), they appear to have been effective at promoting accretion of the upper shoreline with shingle integrating with the rocks, and sand and organic matter now covering rocks (Fig. 8). However, the success of rock placement was met with mixed views by survey respondents. While $50 \%$ of respondents believed the erosion was reduced at the locations at which the rocks were placed, several expressed concerns that the rocks may be deflecting erosion to the shoreline adjacent. At Site B, revegetation of the dune scarp above rock reinforcement has occurred (Fig. 9), however the adjacent Transect 5 (Fig. 5) shows no accretion over the same time period. Installation of hard coastal protection structures can lead to wave refraction and an increase in erosion of the adjacent shoreline (Lumsden 1995), which appears to be occurring at Turners Beach. Community surveys regarding coastal erosion in Latvia showed similar results, with half of the interviewees considering hard coast defence structures to be an effective adaptation measure to erosion, while the other half saw long-term ineffectiveness or other consequences (Apine 2011).

The installation of signs with the intention of communicating conservation information appears to be the least successful management practice, with informal beach access tracks remaining adjacent to these signs. Data obtained from the qualitative survey also confirmed the failure of signs. Only $17 \%$ of the respondents believed that the signs were sufficiently informative, and $55 \%$ considered that the signs did not adequately inform the public about coastal rehabilitation practices and the importance of minimising disturbance to the dunes. Public surveys in South Africa found beach visitors to be poorly informed about beach management issues despite large information signs (Hertling and Lubke 1999), people rather holding personally impressionistic views of the coastal landscape.

\section{Conclusion}

The long term outcomes of shoreline rehabilitation initiatives in managing coastal erosion is a poorly researched area, and assessment using beach profile re-measurement, historical photographs, sediment analysis and qualitative surveys has shown rehabilitation to be largely successful. Public walkways providing access were found to have the best outcomes in minimising human trampling, this directly removing the causes of degradation (Gómez-Pina et al. 2002). The 
installation of vertical poles along the roadside has also been a very successful initiative in reducing impact, as vehicles are now unable to access or park on the shoreline or the areas behind the dunes. Dune fencing was found to be quite successful in preventing human access in certain areas, however disregard of fencing, or damaged fencing has left other sections of the shoreline vulnerable to trampling. Overall, revegetation of dunes with native grasses and shrubs was found to have been successful, leading to dune accretion.

However, the placement of rocks along the shoreline was found to have had mixed success. While erosion has been significantly reduced in the locations where the rocks were placed, erosion of the adjacent shoreline is continuing to occur. The installation of signs with the intention of communicating conservation information was found to have been the least successful management practice, due to indifference shown towards the signs.

Beach profile monitoring of morphology and accretion/ erosion was found to be an effective evaluation method, as also found in southern Europe (Suanez and Bruzzi 1999; Rozé and Lemauviel 2004). Long term datasets describing such natural dynamics of beach systems are fragmentary (Defeo et al. 2009) and such long term monitoring is outside the scope of most projects. Monitoring frameworks were found to be the most uncertain outcome from review of NRM program success (Kelly 2012), however increased capacity for the involvement of surveyors would allow ongoing comprehensive beach monitoring in many countries.

Community participation has been shown by this study to have resulted in rehabilitation success, enabled by small grant funding. Initial observations of degradation by community members led to coordinated volunteer effort to successfully reverse erosion trends and increased the integrity and resilience of the beach and dunes. Use of community survey is confirmed by this study to contribute value to identifying long term change as well as attitudes to success. Such investigations can give insight into causes of changes that may remain undetected by conventional scientific research (Semken et al. 2011). Community survey can be particularly useful where more quantitative data on long term change is unavailable (Mimura and Nunn 1998; Apine 2012).

While this study has evaluated long term outcomes of rehabilitation activities at one location, there is a need for comparative studies at other beaches where such works been undertaken, both in Australia and internationally. This would assist with better planning, prioritisation, and more effective allocation of resources for environmental rehabilitation, justifying the likely effectiveness of such investment.

Acknowledgements The authors are grateful to the Turners Beach Coastcare Group for their encouragement and participation in this study, particularly Patricia Ellison and Wendy Horniblow. Transects were kindly surveyed by Nick Bowden of the Antarctic Climate and Ecosystems
Cooperative Research Centre, University of Tasmania, and historical data for transects 1-3 were provided by the TASMARC program. The authors are also grateful to two anonymous reviewers, whose comments allowed improvements to the paper.

Open Access This article is distributed under the terms of the Creative Commons Attribution License which permits any use, distribution, and reproduction in any medium, provided the original author(s) and the source are credited.

\section{References}

Antarctic Climate \& Ecosystems Cooperative Research Centre (2013) TASMARC database: Turners Beach. http://tasmarc.info. Accessed 26 October 2013

Apine L (2011) Residents' attitude towards possible adaptation measures to the sea coast erosion in Latvia. Int J Clim Change Strategies Manag 3:238-249

Bird ECF (1985) Coastline changes. Wiley \& Sons, New York

Bird ECF (2008) Coastal geomorphology: an introduction, 2nd edn. Wiley \& Sons, Ltd, Chichester

Bureau of Meteorology (2013) Climate Statistics for Australian Locations: Devonport. http://www.bom.gov.au/climate/averages/ tables/cw 091111.shtml. Accessed 24 September 2013

Central Coast Council (2011) Turners beach local area plan: urban design guidelines. Central Coast Council, Ulverstone

Church J, White N, Aarup T, Wilson W, Woodworth P, Domingues C, Hunter J, Lambeck K (2008) Understanding global sea levels: past, present and future. Sustain Sci 3(1):9-22

Davies J (1973) Sediment movement on the Tasmanian coast. First Australian Conference on Coastal Engineering, 1973 Engineering Dynamics of the Coastal Zone Institution of Engineers Australia, Sydney

Davies J (1978) Beach sand and wave energy in Tasmania. In: Davies J, Williams M (eds) Landform evolution in Australasia. Australian National University Press, Canberra, pp 158-167

Davies J, Hudson J (1987) Sources of shore sediment on the north coast of Tasmania. Pap Proc R Soc Tasmania 121:137-151

Defeo O, McLachlan A, Schoeman DS, Schlacher TA, Dugan J, Jones A, Lastra M, Scapini F (2009) Threats to sandy beach ecosystems: a review. Estuar Coast Shelf Sci 81:1-12

DPIWE (Department of Primary Industries Parks Water and Environment) (2012) The LIST (Land Information System Tasmania) LISTmap Turners Beach http://www.thelist.tas.gov.au/ listmap/listmapstart.jsp Accessed 20 August 2012

Dunn K (2000) Interviewing. In: Hay I (ed) Qualitative research methods in human geography. Oxford University Press, South Melbourne, pp $50-82$

Edgar GJ, Barrett NS, Graddon DJ (1999) A classification of Tasmanian estuaries and assessment of their conservation significance using ecological and physical attributes, population and land use. Technical Report, TAFI Marine Research Laboratories, Hobart

Gehrels WR, Callard SL, Moss PT et al (2012) Nineteenth and twentieth century sea-level changes in Tasmania and New Zealand. Earth Planet Sc Lett 315-316:94-102

Gómez-Pina G, Muñoz-Pérez JJ, Ramírez JL, Ley C (2002) Sand dune management problems and techniques, Spain. J Coast Res Spec Issue 36:325-332

Hajkowitz S (2009) The evolution of Australia's natural resource management programs: Towards improving targeting and evaluation of investments. Land Use Policy 26:471-478 
Hayes M, Kirkpatrick JB (2013) Influence of Ammophila arenaria on half a century of vegetation change in eastern Tasmanian sand dune systems. Austr J Bot 60:450-460

Hertling UM, Lubke RA (1999) Use of Ammophila arenaria for dune stabilization in South Africa and its current distribution- perceptions and problems. Environ Manag 24:467-482

Hunter J, Coleman R, Pugh D (2003) The sea level at Port Arthur Tasmania, from 1841 to the present. Geophys Res Lett 30(7):541-54-4 doi:10.1029/2002GL016813

Hydro Tasmania (2013) Mersey-Forth Catchment. http://www.hydro. com.au/energy/our-power-stations/mersey-forth\#item-554. Accessed 18 August 2013

Kelly R (2012) Evaluating collaborative landscape research: views of participants and end users. In: Lefroy T, Curtis A, Jakeman A, McKee J (eds) Landscape logic. CSIRO, Collingwood, pp 267282

Landi M, Ricceri C, Angiolini C (2012) Evaluation of dune rehabilitation after 95 years by comparison of vegetation in disturbed and natural sites. J Coast Res 28(5):1130-1141

Lefroy T, Curtis A, Jakeman A, McKee J (2012) Introduction: Improving the evidence base for natural resource management. In: Lefroy $\mathrm{T}$, Curtis A, Jakeman A, McKee J (eds) Landscape logic. CSIRO, Collingwood, pp 1-6

Lumsden J (1995) Beach management - putting seawalls in their place. Trans Inst Prof Eng N Z Civil Eng Sect 22(1):38-42

McManus J (1988) Grain size determination and interpretation. In: Tucker M (ed) Techniques in sedimentology. Blackwell Scientific Publications, Oxford, pp 63-85

Mimura N, Nunn PD (1998) Trends of beach erosion and shoreline protection in rural Fiji. J Coast Res 14:37-46

Nicholls RJ, Wong PP, Burkett VR et al (2007) Coastal systems and lowlying areas. In: Parry ML, Canziani OF, Palutikof JP et al (eds) Climate Change 2007: Impacts, adaptation and vulnerability. Contribution of Working Group II to the Fourth Assessment Report of the Intergovernmental Panel on Climate Change. Cambridge University Press, Cambridge, pp 315-356

Nichols G (2009) Sedimentology and stratigraphy, 2nd edn. WileyBlackwell, West Sussex

Pettijohn F (1975) Sedimentary rocks. Harper \& Row, Publishers, Inc., New York
Pugh DT (1987) Tides, surges and mean sea-level. John Wiley and Sons, Chichester

Robins L, Kanowski P (2011) "Crying for our country": eight ways in which "Caring for our country" has undermined Australia's regional model for natural resource management. Australas J Environ Manag 18:88-108

Ross J, Crawford C, Gibson J, Gallagher B, Beard J, McGowan S (2012) Improving the utility and sensitivity of estuarine monitoring. In: Lefroy T, Curtis A, Jakeman A, McKee J (eds) Landscape logic. CSIRO, Collingwood, pp 39-50

Rozé F, Lemauviel S (2004) Sand dune restoration in North Brittany, France: a 10-year monitoring study. Restor Ecol 12:29-35

Sandery PA, Kampf J (2007) Transport timescales for identifying seasonal variation in Bass Strait, south-eastern Australia. Estuar Coast Shelf Sci 74:684-696

Santoro R, Jucker T, Prisco I, Carboni M, Battisti C, Acosta ATR (2012) Effects of trampling limitation on coastal dune plant communities. Environ Manag. doi:10.1007/s00267-012-9809-6

Semken M, Miller KK, James K (2011) The value of oral history in natural resource management: the Balcombe estuary reserve, Mount Martha, Victoria. Australas J Environ Manag 18:109-122

Short A (2006) Beaches of the Tasmanian coast and islands: a guide to their nature, characteristics, surf and safety. Sydney University Press, Sydney

Suanez S, Bruzzi C (1999) Shoreline management and its implications for coastal processes in the eastern part of the Rhone Delta. J Coast Conserv 5:1-12

Thom B, Roy P (1985) Relative sea levels and coastal sedimentation in southeast Australia in the Holocene. J Sediment Petrol 55(2):257264

Webb CE, Oliver I, Pik AJ (2001) Does coastal foredune stabilization with Ammophila arenaria restore plant and Arthropod communities in Southeastern Australia? Restor Ecol 8:283-288

Youl R, Marriott S, Nabben T (2006) Landcare in Australia - A summary of the development of the landcare movement in Australia. http:// www.daff.gov.au/natural-resources/landcare/publications/landcareaustralia . Accessed 6 June 2014

Zann LP (1995) Our Sea, Our Future: Major findings of the state of the marine environment report for Australia. Great Barrier Reef Marine Park Authority Townsville 